\title{
Reproductive biology of Ophiocoma aethiops and O. alexandri (Echinodermata: Ophiuroidea) from Estacahuite Bay, Oaxaca, Mexico
}

\author{
Francisco Benítez-Villalobos ${ }^{1, *}$, Catalina Aguilar-Duarte ${ }^{2}$, \\ Omar Hernando Avila-Poveda ${ }^{2}$ \\ ${ }^{1}$ Instituto de Recursos and ${ }^{2}$ División de Estudios de Posgrado, Universidad del Mar (UMAR), Campus Puerto Ángel, \\ Distrito de San Pedro Pochutla, Puerto Ángel, Oaxaca 70902, México
}

\begin{abstract}
The reproductive biology of Ophiocoma aethiops and O. alexandri was analyzed based on monthly time-series samples from May 2009 to April 2010 at Estacahuite Bay, Oaxaca, in the Mexican tropical Pacific Ocean. We evaluated the relationship between the reproductive biology of both species and variations of sea-bottom temperature, salinity, pluvial precipitation, photoperiod (light hours) and chlorophyll. Sex ratio, gonadosomatic index (GSI), actual fecundity and oocyte size were determined. Monthly variations of the environmental factors were compared with variations of GSI. Both species are gonochoric ophiuroids and the ratio of males to females (1:1) was not significantly different throughout the year. There were significant differences in GSI values between the 2 species, but temporal variation patterns were similar. Gametogenesis showed synchrony among males and females and 4 stages were recognized for both sexes. Spawning occurred in females of $O$. aethiops from May to November and from April to December in $O$. alexandri. Main spawning for males of both species occurred from May to December, although there was always availability of mature spermatozoa. Mean oocyte size was 32 to $58 \mu \mathrm{m}$ for $O$. alexandri and 47 to $63 \mu \mathrm{m}$ for $O$. aethiops. Mean \pm SD fecundity was $3.03 \pm 1.72$ million vitellogenic oocytes per female for $O$. aethiops and $1.61 \pm 0.99$ million for $O$. alexandri. The reproductive patterns of $O$. aethiops and $O$. alexandri are influenced by the local oceanic dynamics, as has been reported for other echinoderm species in the area, but they also have a high genetic (endogenous) element, because the observed patterns resemble those determined for the Panamian populations of these 2 species.
\end{abstract}

KEY WORDS: Echinoderms - Brittle stars - Ophiocoma - Reproductive cycle - Fecundity · Histology · Mexican Pacific · Environmental factors

\section{INTRODUCTION}

For a number of marine invertebrates, reproductive biology is one of the most important traits in their life history (Stancyk 1979, Avila-Poveda 2004, BenítezVillalobos 2005, Grange 2005, Wong et al. 2011), and research indicates that it changes with latitude and according to environmental factors (Pearse 1968, Bower et al. 2002, Guest et al. 2005, Mercier \& Hamel 2009). In marine invertebrates, large spatial scales generate diverse reproductive patterns (Roy et al. 1998, Ramirez-Llodra 2001, Bower et al. 2002, AvilaPoveda \& Baqueiro-Cardenas 2009, Benítez-Villalobos \& Díaz-Martínez 2010). 
Studies on the reproductive biology of ophiuroid species have been carried out mainly in high latitudes and deep waters (Ramirez-Llodra 2001, Williams \& Bentley 2002, Falkner \& Byrne 2003, Tominaga et al. 2004, Grange 2005, Soong et al. 2005, Byrne et al. 2008). In those investigations temperature fluctuation has been considered as one of the most important physical factors that affects periodicity of the reproductive cycle in temperate waters; whereas, in tropical environments where isothermal conditions prevail, the influence of other physical and chemical factors, such as salinity, photoperiod, tides and currents, is more important (Giese \& Pearse 1974, Stancyk 1979, Böttger et al. 2004). Stephenson (1934) indicated that in temperate waters, a minimal fluctuation in temperature could induce the organism to spawn during the warm months. Nevertheless, Pearse (1968) and Giese \& Pearse (1974) established that seasonality in reproductive cycles of marine invertebrates tends to be stronger as the latitude increases.

A few studies regarding reproductive biology have been carried out for the ophiuroid genus Ophiocoma, mainly in the Atlantic and Caribbean regions (Hendler 1975, 1979, 1991). Those works show that different species exhibit variations in their reproductive cycles, which are closely related to the latitudinal gradient, and that the most important factor producing those variations is the difference in the rainfall season among localities.

Ophiocoma aethiops and O. alexandri are the only species of this genus reported for the American Pacific Ocean, and they constitute an important percentage of biomass in benthic and coral reef ecosystems, playing key roles in the dynamics of those communities (Hendler 1979). Even though geographic distribution of the 2 species ranges from the Gulf of California $\left(\sim 31^{\circ} \mathrm{N}\right.$ latitude) to Ecuador $\left(\sim 3^{\circ} \mathrm{S}\right.$ latitude, including the Galápagos Islands), the reproductive biology of $O$. aethiops and $O$. alexandri has been studied only in Panama $\left(\sim 8^{\circ} \mathrm{N}\right.$ latitude $)$ (Hendler 1979). This fact highlights the necessity to increase the knowledge of the reproductive cycles of these species and their relationship with environmental factors. The purpose of this study was to analyze the reproductive biology of $O$. aethiops and O. alexandri in Estacahuite Bay, Oaxaca, Mexico $\left(\sim 15^{\circ} \mathrm{N}\right.$ latitude) and to determine the relationship between their reproductive patterns and variations of environmental factors, i.e. sea-bottom temperature, salinity, pluvial precipitation, photoperiod and chlorophyll.

\section{MATERIALS AND METHODS}

\section{Sampling and measurements}

About 20 individuals of each of the 2 species of brittle stars, Ophiocoma aethiops and $O$. alexandri, were haphazardly collected by SCUBA diving every month for one year between May 2009 and April 2010, from a depth interval of 3 to $15 \mathrm{~m}$ in Estacahuite Bay, Oaxaca $\left(15^{\circ} 40^{\prime} 5.57^{\prime \prime} \mathrm{N}, 96^{\circ} 28^{\prime} 53.61^{\prime \prime} \mathrm{W}\right)$, off the Pacific Coast of southern Mexico. All individuals were narcotized by leaving them in seawater at $2^{\circ} \mathrm{C}$ for $24 \mathrm{~h}$ before dissection (Lincoln \& Sheals 1979). Later, individuals were fixed in $10 \%$ neutral formalin saline solution in seawater for $12 \mathrm{~h}$ and preserved in $70 \%$ ethanol (Grange et al. 2004, Avila-Poveda et al. 2009). The damp-dry weight of the disc without arms (DW, $\pm 0.001 \mathrm{~g}$ ) was recorded (Fenaux 1970, Hendler 1979). The 10 gonads of every specimen were dissected out by opening the aboral side of the disc, and then the damp-dry weight of total gonads (GW, $\pm 0.001 \mathrm{~g})$ was recorded. The total gonad volumes $(\mathrm{GV}, \pm 0.001 \mathrm{ml})$ were measured by the displacement of fluid method until a hydrostatic equilibrium was reached, using a variation of the Mohr-Westphal balance (Scherle 1970, Nagy \& Pieri 1975).

During each monthly collection, salinity was measured using a waterproof multiparameter meter (HANNA HI 9828), while temperature was recorded at $1 \mathrm{~h}$ intervals using a pendant data logger (HOBO) permanently attached to the bottom. Data for pluvial precipitation (rainfall), photoperiod (light hours) and chlorophyll were obtained monthly from online databases (www.wunderground.com/ and http://oceancolor.gsfc.nasa.gov/, respectively). Monthly means were calculated for every parameter recorded.

\section{Histological procedure and microscopy examination}

Preserved gonads were dehydrated in a series of graded ethanol solutions ( $2 \mathrm{~h}$ baths with 2 changes for each solution of 70, 96 and $100 \%$ ethanol), cleared in Citrisolv (45 min baths with 3 changes), infiltrated in Paraplast paraffin with a $56^{\circ} \mathrm{C}$ melting point ( $1 \mathrm{~h}$ baths with 4 changes) and embedded in Paraplast paraffin with the aid of an embedding machine. Serial sections were cut at $7 \mu \mathrm{m}$ thickness using a manual rotary microtome (LEICA RM2145), later mounted on glass slides and stained with the routine Harris hematoxylin-eosin regressive method $\left(\mathrm{HHE}_{2}\right.$ : Luna 1968, Howard \& Smith 1983). Slide 
examinations were performed at visual magnifications of 30x, 100x and 400x and digital images were achieved with a digital camera Logitech HD ProWebCam C910 mounted on a microscope (Olympus CX21) and stored in computer in graphic format. Adobe Photoshop CS2, v.9.0, was used to produce the artwork for the figures.

\section{Reproductive traits}

Gonad developmental stages (GDSs) for each sex were defined by matching the most outstanding histological features throughout the development process of the gonad (i.e. frequency, size and features of gametes, presence/absence of phagocytes, as well as thickness and presence/absence of a gonadal wall of fibrous networks) with the GDS used for other ophiuroid species (Cuénot 1888, Selvakumaraswamy \& Byrne 1995, Stewart \& Mladenov 1995, Falkner \& Byrne 2003, Tominaga et al. 2004, Borges et al. 2009). For both sexes 4 stages were designated: gametogenesis, mature, spawning and post-spawning.

Sex ratio (male:female) was calculated annually, and deviation from the expected ratio of 1:1 was tested with the chi-square $\left(\chi^{2}\right)$ test (Sokal \& Rohlf 1995). A general gross anatomy description of the gonad was performed. The gonadosomatic index (GSI) for each species and sex was calculated monthly as: $\mathrm{GSI}=(\mathrm{GW} / \mathrm{DW}) \times 100$.

Fecundity was quantified as the number of vitellogenic oocytes per female (actual fecundity) from the mean volume of oocytes and the GV in each female (Ramirez-Llodra 2001，2002, Ramirez-Llodra et al. 2002). Oocyte size of at least 100 oocytes per female per species was measured through sections of the nucleolus (Ramirez-Llodra et al. 2002), using the following tool: Feret's diameter measurement (i.e. the longest distance between any 2 points along the selection perimeter, also known as maximum caliper; Walton 1948) with the image analysis package Image J 1.41 (National Institutes of Health).

\section{Statistical analysis}

General data were expressed as mean \pm SE. Statistical differences in GSI were tested using 2-way ANOVA (sex and month as factors), while differences in fecundity for females were tested using ANOVA. Relations among temperature, salinity, pluvial precipitation, photoperiod and chlorophyll (independent variables) with the reproductive cycle of
Ophiocoma aethiops and O. alexandri represented by GSI (dependent variables) were assessed through a step-by-step multiple linear regression analysis. Statistical analyses were carried out using the computer program STATISTICA 6 and SigmaStat 3.5. Statistical significance was accepted at $\mathrm{p}<0.05$.

\section{RESULTS}

\section{Sex ratio and gross anatomy of gonads}

Ophiocoma aethiops and $O$. alexandri did not show sexual dimorphism, and it was confirmed that they are gonochoric ophiuroids, since none of the 427 organisms examined histologically (202 of O. aethiops and 225 of $O$. alexandri) showed ovotestes, i.e. they are not hermaphrodites. The ratio of males to females did not differ significantly and showed a 1:1 proportion throughout the year $\left(\chi^{2}=0.99, p=0.3270\right)$ for $O$. aethiops and $\left(\chi^{2}=1.44, \mathrm{p}=0.2008\right)$ for O. alexandri.

The macroscopic anatomy of the gonad was that of a sac (i.e. thin and transparent epithelium), which contained a number of smaller oval sacs, herein called follicles. Those small sacs were whitish in males and varied from pink to purple in females. Occasionally the sacs had 1 or 2 ramifications. Every gonad was located at both sides of the bursal slits, constituting 10 discrete units that could be identified in the disc of an individual.

All gonad development stages were found in the 427 examined organisms (202 of Ophiocoma aethiops and 225 of $O$. alexandri) throughout the year, but for males of both species, the gametogenesis and mature stages were histologically similar; consequently both stages were represented together in the reproductive cycle (see Fig. 6). Sporadically one developmental stage concurred with the previous or the subsequent stage within isolated follicles of the same gonad and/or within gonads of the same individual. In general, microscopic analysis allowed the histological differentiation of the structural components through the development process of the gonad and the sexual cells, i.e. gametes, and presence/absence of phagocytes, as well as thickness and presence (only during post-spawning) or absence of a gonadal wall of fibrous networks (Figs. 1 to 4). On the other hand, the ovaries (Figs. $1 \& 2$ ) and testes (Figs. $3 \& 4$ ) of both species are sheltered by a follicular wall consisting of 2 layers of tissue: the internal and external sacs and the genital coelomic sinus that separates them. The external sac constitutes the visceral peritoneum, 


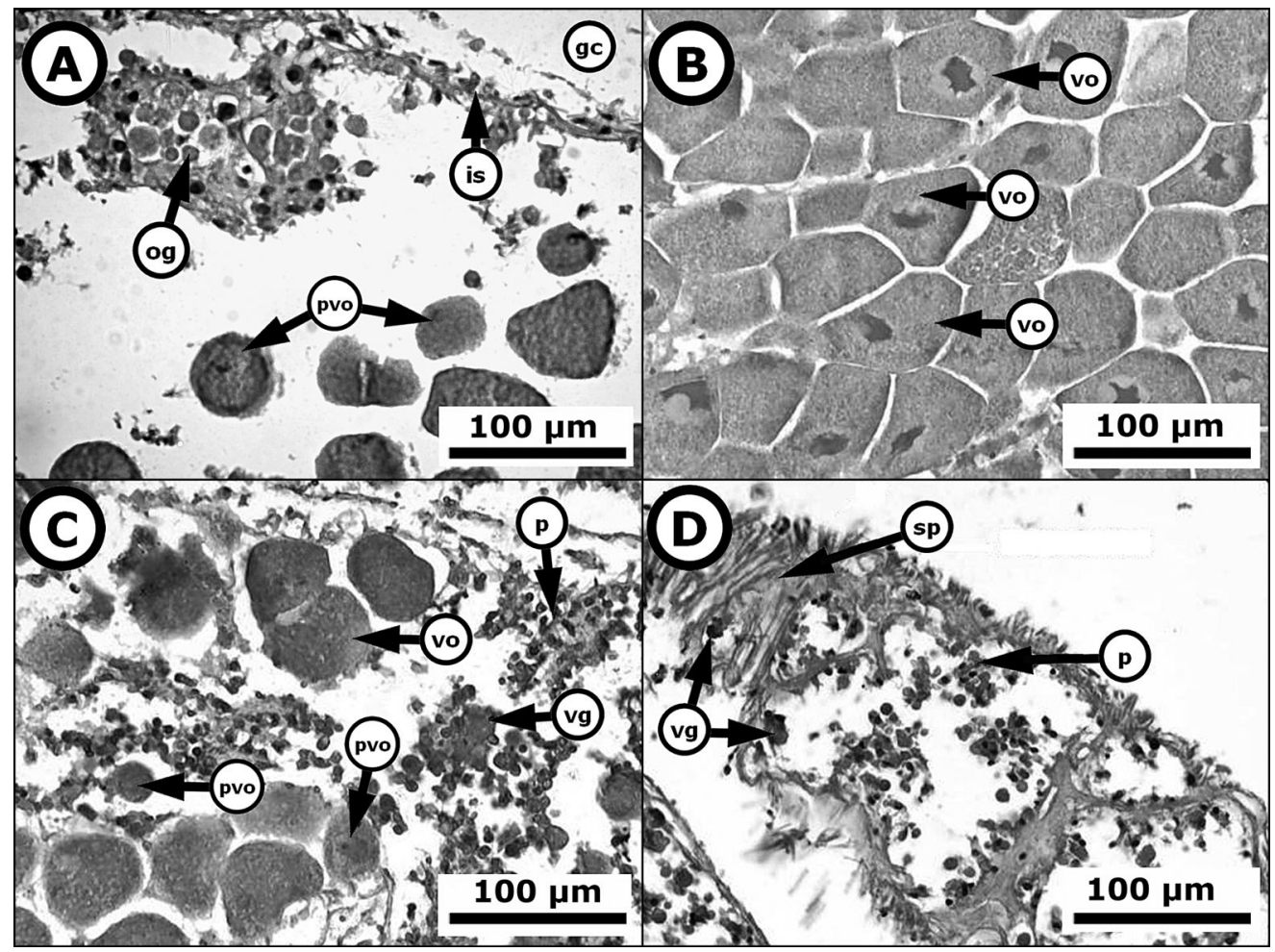

Fig. 1. Ophiocoma aethiops. Light microscopy of the histology of the ovaries: (A) gametogenesis, (B) mature, (C) spawning, (D) post-spawning. gc: genital coelom; is: internal sac; og: oogonia; p: phagocytes; pvo: pre-vitellogenic oocyte; sp: spicules; vg: vitellin granule; vo: vitellogenic oocyte

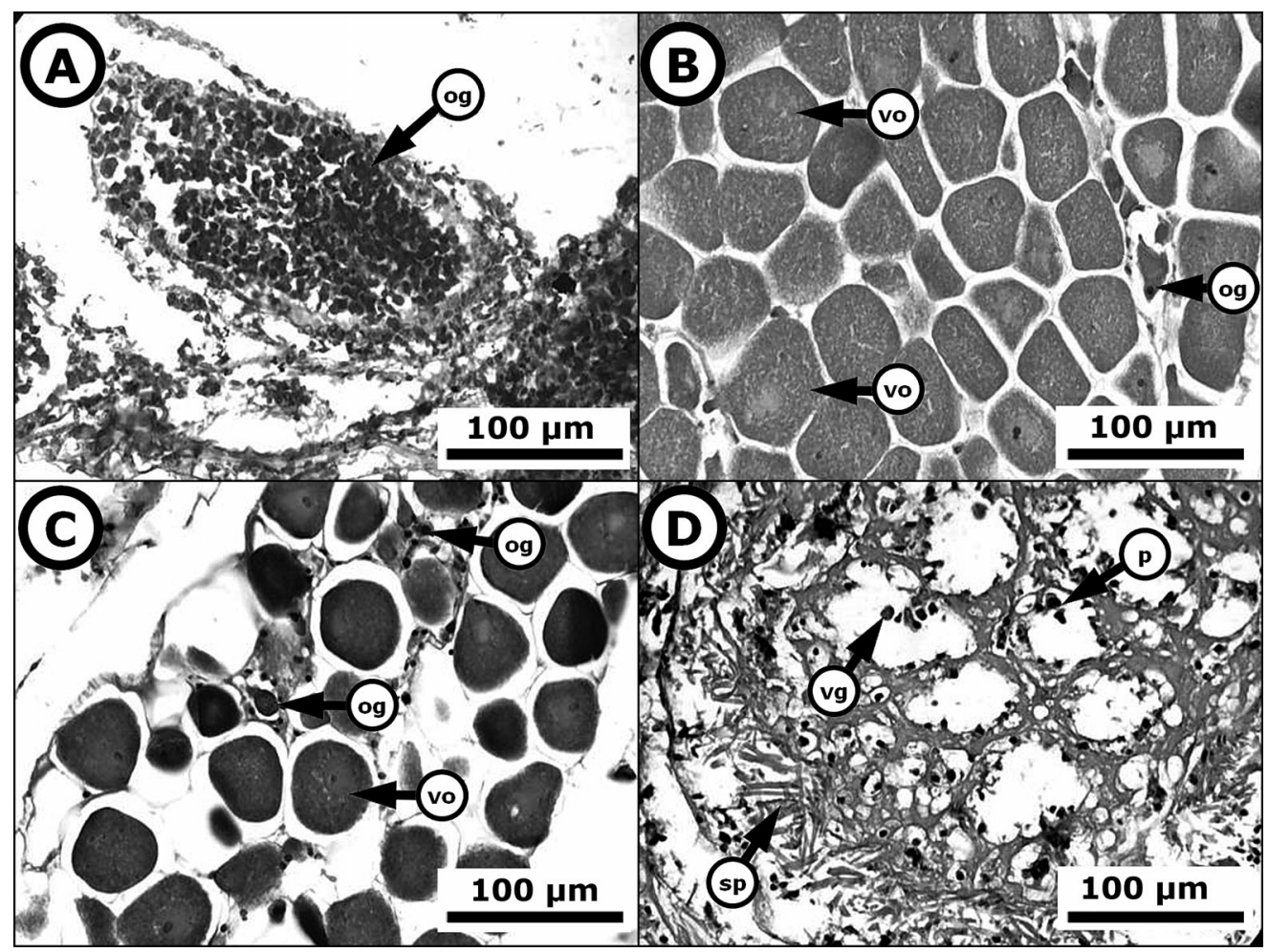

Fig. 2. Ophiocoma alexandri. Light microscopy of the histology of the ovaries: (A) gametogenesis, (B) mature, (C) spawning, (D) post-spawning. og: oogonia; p: phagocytes; sp: spicules; vg: vitellin granule; vo: vitellogenic oocyte 


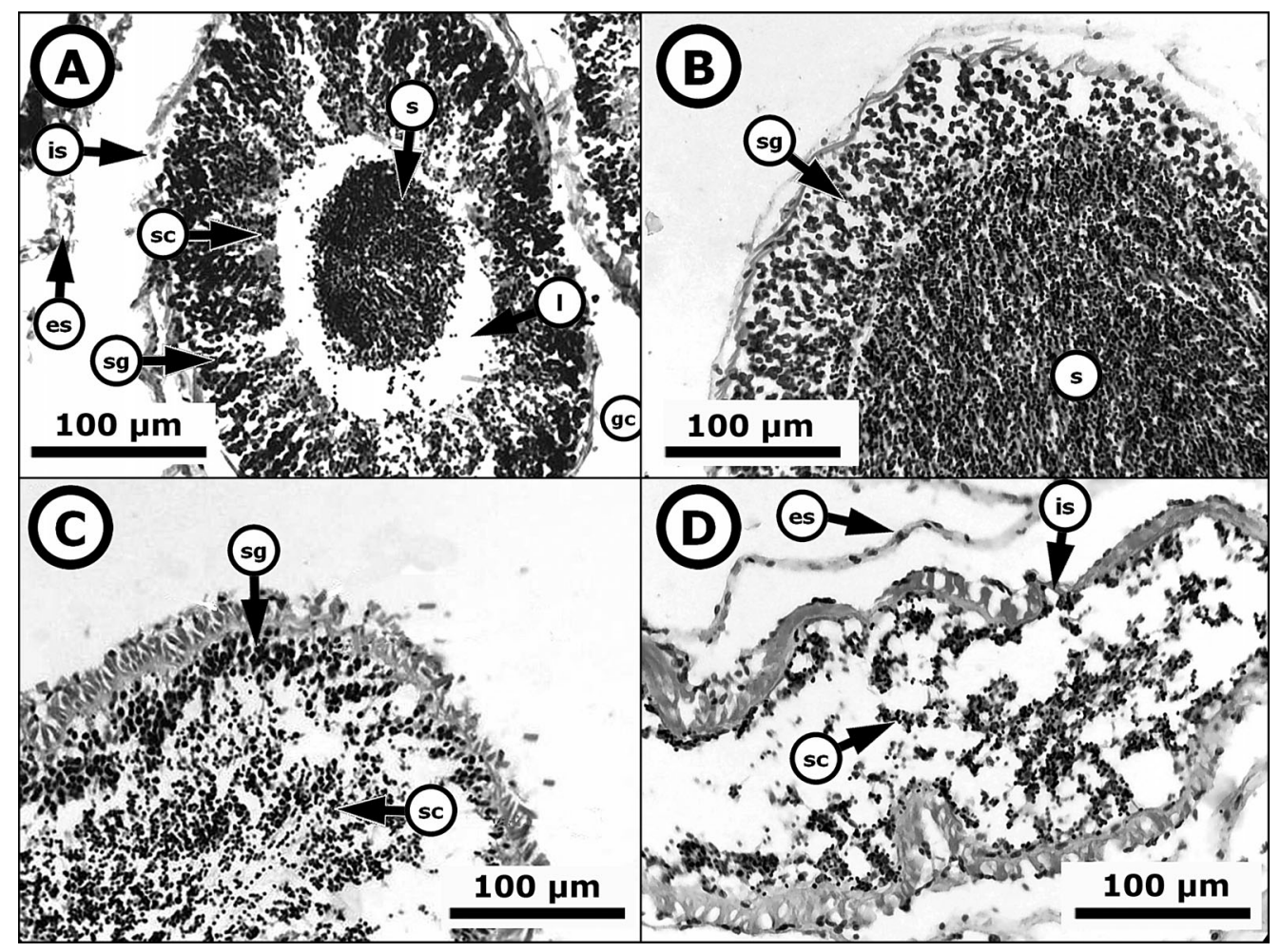

Fig. 3. Ophiocoma aethiops. Light microscopy of the histology of the testes: (A) gametogenesis, (B) mature, (C) spawning, (D) post-spawning. es: external sac; gc: genital coelom; is: internal sac; l: lumen; s: spermatozoa; sc: spermatocytes; sg: spermatogonia

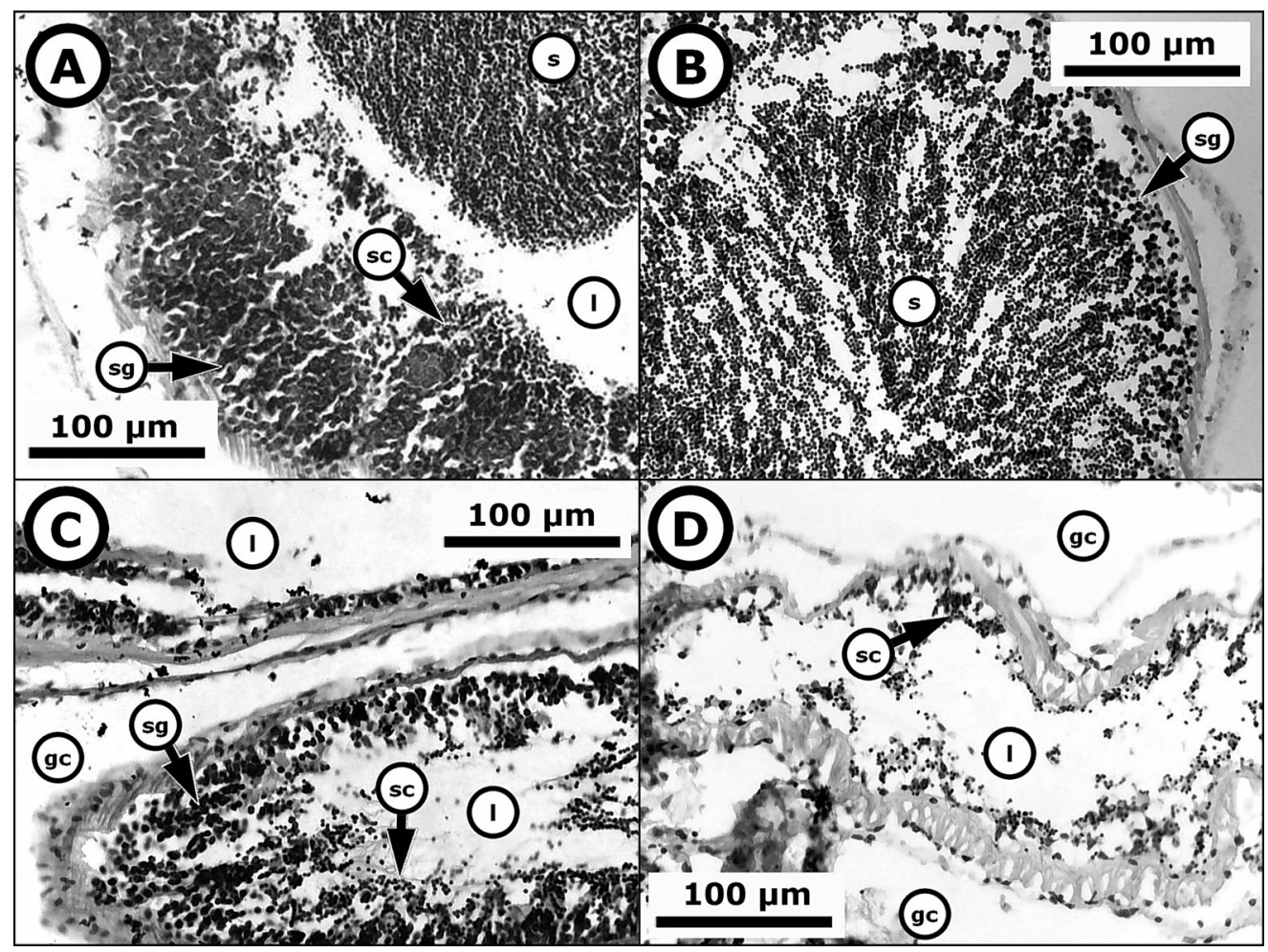

Fig. 4. Ophiocoma alexandri. Light microscopy of the histology of the testes: (A) gametogenesis, (B) mature, (C) spawning, (D) post-spawning. gc: genital coelom; l: lumen; s: spermatozoa; sc: spermatocytes; sg: spermatogonia 
whereas the internal sac constitutes the gonadal tunica.

\section{Reproductive cycles}

In females of Ophiocoma aethiops, spawning was observed from May to November with frequencies above $40 \%$. The post-spawning stage appeared during August (17\%) and was mainly observed from November to February with the highest frequency in December $(100 \%)$. The gametogenesis stage occurred from January to March with the highest frequency in February $(80 \%)$. The mature stage occurred from June to September (40 to $11 \%$ ) and from January to April with more than $67 \%$ mature (Fig. 5A).

The cycle of Ophiocoma alexandri was slightly different from that of $O$. aethiops. Spawning was observed from May to December with the highest frequency above $65 \%$, and also during April with $33 \%$. Post-spawning occurred during October to November and in February with the highest frequency in November (64\%). The gametogenesis stage occurred in May $(25 \%)$, but was observed mainly during Jan-

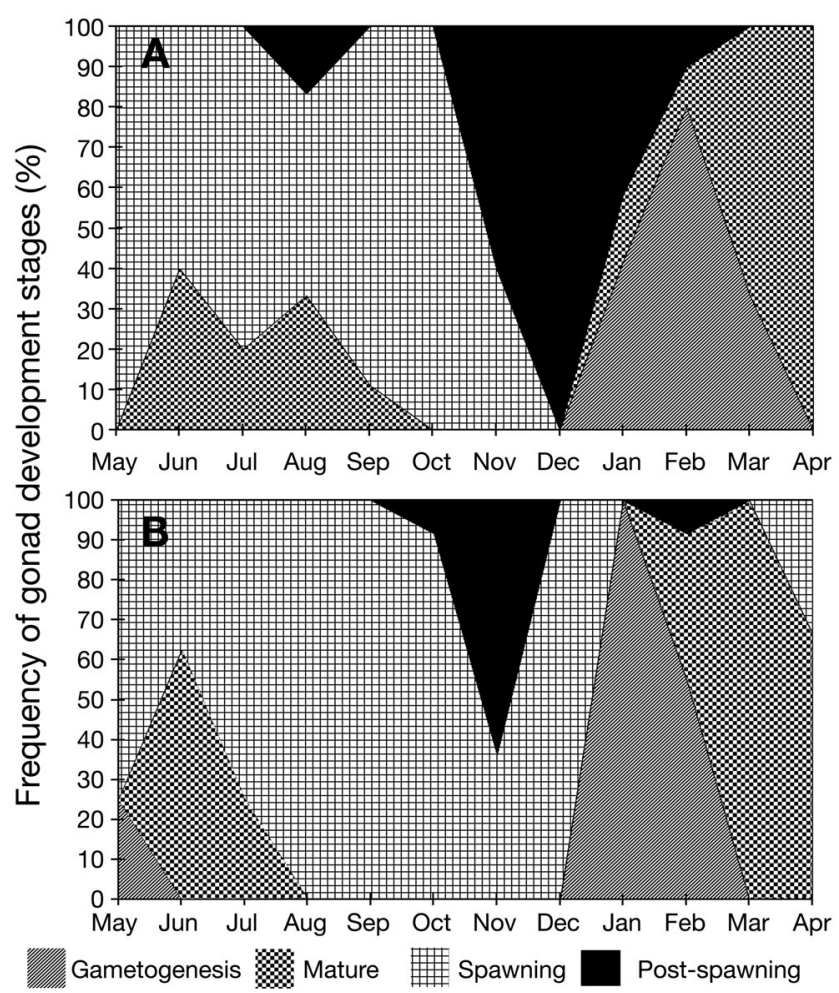

Fig. 5. Ophiocoma aethiops and O. alexandri. Female gametogenic cycle of (A) O. aethiops and (B) O. alexandri from May 2009 to April 2010 at Estacahuite Bay, Oaxaca, Mexico uary $(100 \%)$ to February. The mature stage occurred during June and July and from February to April, with frequencies above $63 \%$ during March and June (Fig. 5B).

In males, it was evident for both species that spawning occurs throughout the year, with the highest frequencies occurring from May to October (>70\%). Post-spawning was present from October to January in Ophiocoma aethiops, and from October to February in O. alexandri, and the highest frequency occurred in December $(>60 \%)$ for both species. Gametogenesis and mature stages were observed in $O$. aethiops during December and from February to April, whereas for $O$. alexandri these stages occurred from May to July, during October, and from January to April, and the highest frequency was apparent in February and/or March ( 60\%) for both species (Fig. 6).

\section{Gonadosomatic index}

The GSI of each sex per species displayed a similar fluctuation pattern between the same sexes of the 2 species throughout all the months of the study, and tended to increase together, but it was more pro-

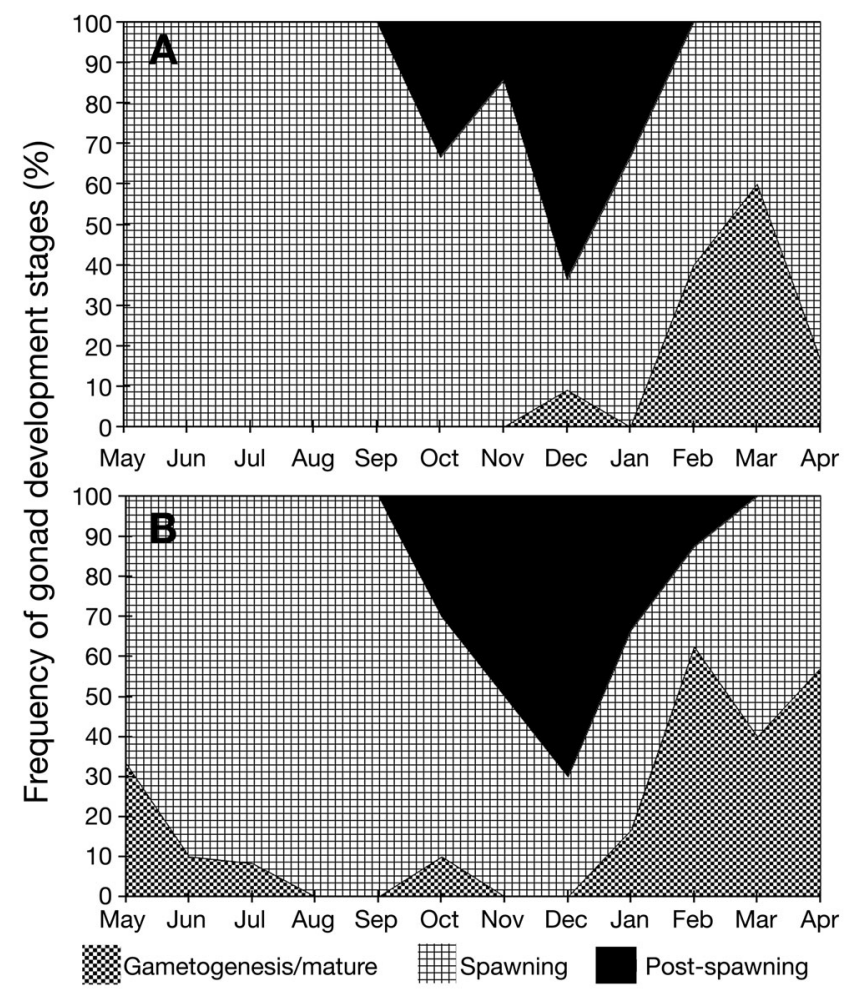

Fig. 6. Ophiocoma aethiops and O. alexandri. Male gametogenic cycle of (A) O. aethiops and (B) O. alexandri from May 2009 to April 2010 at Estacahuite Bay, Oaxaca, Mexico 
nounced and higher for Ophiocoma alexandri than for $O$. aethiops, although slightly more pronounced in males than in females (Fig. 7). In females and males, maximum average values were found around September and during April, suggesting a synchronism between males and females.

Mean $( \pm$ SD) GSI values of males and females combined were $13.66 \pm 6.57$ for Ophiocoma aethiops and $19.88 \pm 12.72$ for $O$. alexandri. Monthly variations of GSI throughout the sampling year were statistically significant for both species $(F=9.999$ and 16.151, $\mathrm{p}<$ 0.001 , for $O$. aethiops and $O$. alexandri, respectively). There were also significant differences in variations of GSI between species for the sampling period $(F=$ $4.255, \mathrm{p}<0.001)$. The observed differences were the result of values from July to December and April (Tukey's test: July q $=3.656$, August $q=5.012$, September $\mathrm{q}=8.816$, October $\mathrm{q}=5.530$, November $\mathrm{q}=$ 2.952, April $\mathrm{q}=4.542, \mathrm{p}<0.05)$.

The comparison of GSI between sexes did not show significant differences in Ophiocoma alexandri $(F=$

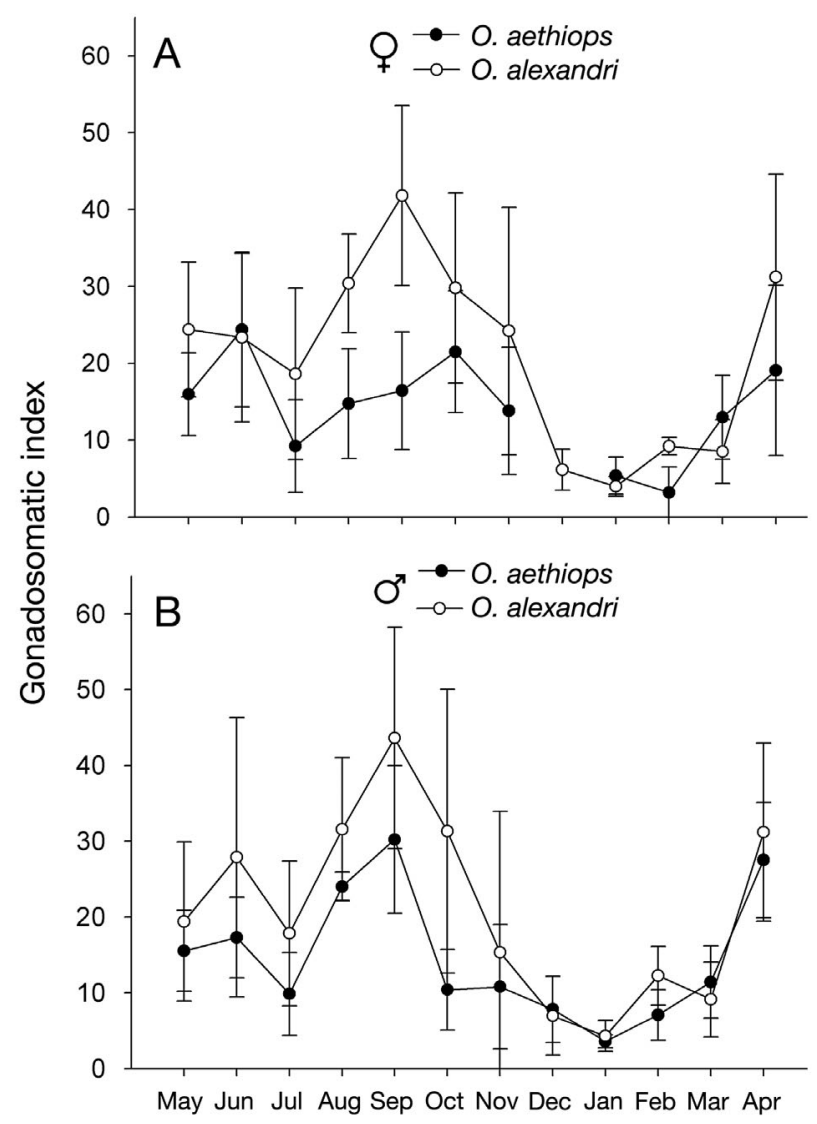

Fig. 7. Ophiocoma aethiops and $O$. alexandri. Monthly mean values $( \pm \mathrm{SD})$ of GSI for $(\mathrm{A})$ females and (B) males of both species from May 2009 to April 2010 at Estacahuite Bay, Oaxaca, Mexico (December data for females of O. aethiops missing)
0.395, $\mathrm{p}=0.957$ ), whereas for $O$. aethiops there were significant differences $(F=3.032, \mathrm{p}=0.002)$. Those differences were determined for values from June, September, October and April (Tukey's test: June q = 3.014, September $\mathrm{q}=4.082$, October $\mathrm{q}=4.098$, April $\mathrm{q}=2.978, \mathrm{p}<0.05)$.

\section{Fecundity and oocyte size}

Actual mean $( \pm \mathrm{SD})$ fecundity was $3.03 \pm 1.72$ million eggs female ${ }^{-1}$ for Ophiocoma aethiops and $1.61 \pm 0.99$ million eggs female ${ }^{-1}$ for $O$. alexandri. Fluctuations in fecundity values throughout the year showed significant differences for both species ( $F=4.837, \mathrm{p}<0.001$ for $O$. aethiops, and $F=2.067$, $\mathrm{p}=0.038$ for $O$. alexandri). There were significant differences also when fecundity of both species was compared $(F=1.926, \mathrm{p}=0.047)$, which occurred in May and June (Tukey's test: May q = 3.023, June $q=6.398, p<0.005)$. Apparently, fecundity is related to the size of the organisms, as individuals of $O$. aethiops are larger $(\sim 35 \mathrm{~mm}$ disc diameter) than those of $O$. alexandri $(\sim 25 \mathrm{~mm}$ disc diameter).

Mean diameter of oocytes oscillated between 47 and $63 \mu \mathrm{m}$ for Ophiocoma aethiops and from 32 to $58 \mu \mathrm{m}$ for $O$. alexandri, and vitellogenic oocytes were present during the entire sampling period. Oocyte size class of 10 to $40 \mu \mathrm{m}$ had a permanent stock along the year. Oocytes within the size class of 40 to $70 \mu \mathrm{m}$ for $O$. alexandri and 40 to $80 \mu \mathrm{m}$ for $O$. aethiops were present during the entire sampling period, except in December. Size classes larger than 70 and $80 \mu \mathrm{m}$ for $O$. alexandri and $O$. aethiops, respectively, did not exceed $5 \%$ in any month.

\section{Reproductive traits versus environmental factors}

The multiple regression analysis of GSI pooled for both sexes of Ophiocoma aethiops with respect to the environmental factors was performed in 3 steps, resulting in the following model:

$$
\text { GSI }=-44.31+0.475 \mathrm{PP}+0.326 \mathrm{PH}
$$

where PP represents pluvial precipitation and $\mathrm{PH}$ is photoperiod. The model showed that the total explained variance over the GSI, in terms of the selected environmental factors, was $53.7 \%\left(R^{2}=0.537\right.$, $\mathrm{R}=0.732$, p multiple $<0.05$ ), indicating that the variables pluvial precipitation and photoperiod are correlated $73.2 \%$ with GSI. 
Regarding GSI pooled for both sexes of Ophiocoma alexandri, the analysis was performed in one step, resulting in the following model:

$$
\text { GSI }=-119.93+0740 T
$$

where $T$ represents temperature. This model showed that the total explained variance over the GSI was $54.7 \%$ with a correlation value of $74 \%$ between temperature and GSI $\left(\mathrm{R}^{2}=0.547, \mathrm{R}=0.740, \mathrm{p}\right.$ multiple $<0.05)$.

\section{DISCUSSION}

According to the histological analysis, GSI and fecundity, we concluded that Ophiocoma aethiops and $O$. alexandri exhibit a semi-continuous reproductive cycle and that females have a long spawning season, which oscillates between April and December. Males showed availability of mature sperm throughout the year, and with almost continuous gametogenesis, except for a few months when the gonads temporally cease the process and the postspawning stage is noticeable.

Because the development of ovaries was variable, some females showed eggs with synchronic development, whereas in others it was asynchronic. The sporadic concurrence of previous or subsequent developmental stages within gonads of the same individual occurred in females that were clearly classified in one of the stages, providing evidence that for these species, the start of every developmental stage may possibly differ by at least $1 \mathrm{mo}$, especially at the start of spawning.

Spawning for some ophiuroid species is short and highly synchronous, whereas for other species it is characterized by a relatively long spawning period followed by a shorter period of low activity or absence of gamete release (Falkner \& Byrne 2003). In the present study, both species conformed to the second pattern, as the spawning period lasted approximately 7 mo and variations in mean fecundity indicated a strong pulse of gamete release during which time the number of oocytes decreased abruptly, whereas during the following pulses the decrease was less conspicuous.

The synchrony of spawning may involve diverse physical and biological factors related to signals in the environment, among which endogenous mechanisms of biological clocks can be found (Soong et al. 2005). Consequently, several species in tropical regions show a single reproductive season during the year, and in some species with an extensive geographical distribution, reproduction may occur throughout the year in populations close to the equator, whereas it may be seasonal in those located at different latitudes (Giese \& Pearse 1974).

Giese \& Pearse (1974) mentioned that the duration of breeding seasons might be important to provide larvae or juveniles with favorable environmental conditions. Baker (1938) recognized 2 causes of reproductive seasonality: (1) exogenous factors, which serve as clues to synchronize the cycles, and (2) environmental conditions that exert selective (evolutionary) pressure, favoring one season for reproduction over others for a given species. Baker (1938) distinguished these as proximate and ultimate causes, respectively.

Models regarding fecundity establish that if food is scarce, the reproductive success decreases for species in which their strategy involves small egg size, whereas it increases when the egg size is larger. However, when availability of food is high, the reproductive success is high even for species with a small egg size (McEdward \& Miner 2003, Grange et al. 2004). Regarding the 2 ophiuroids we studied, which have an apparent planktotrophic strategy with a high number of small eggs similar to other species previously studied (Selvakumaraswamy \& Byrne 2000), food levels are sufficient to satisfy the requirements of larvae and juveniles. We make this conclusion because the spawning season does not coincide with peaks of chlorophyll (increases in primary production) and there is no significant correlation between spawning (represented by GSI) and chlorophyll values. We conclude that the larvae of Ophiocoma aethiops and $O$. alexandri do not depend on pulses of primary production for survival. This observation agrees with that of Hendler (1979), who reported a spawning period similar to the one determined in the present study for Panamanian populations of these 2 species. Moreover, Hendler (1979) also compared the spawning timing with increases in primary production and found that there was no correlation.

In spite of this, the statistical analysis revealed a significant correlation between reproductive cycle (GSI) and temperature, photoperiod and pluvial precipitation; the amount of explained variance is lower than $60 \%$, which suggests that those environmental variables are not determinant for the cycle. When our results were compared with those of Hendler (1979) for Panama, it was evident that the reproductive cycles of the populations coincide, which led us to conclude that the reproductive patterns of Ophiocoma aethiops and $O$. alexandri are not determined by local dynamics, as otherwise occurs with other 
echinoderm species in the area (Benítez-Villalobos \& Martínez-García 2012). Consequently, we propose that the general pattern of reproduction has a high genetic (endogenous) element, because different populations of these ophiuroids living at dissimilar latitudes show very comparable reproductive patterns. Local dynamics of the environmental factors probably adjust those patterns to a short-term particular scale, with possible inter-annual fluctuations.

Acknowledgements. This work is part of the MSc thesis of C. Aguilar-Duarte at the Universidad del Mar (UMAR), which was sponsored by CONACYT through a scholarship. The present study was partially financed by the Project 'Patrones reproductivos de tres especies de equinodermos asociados a arrecife en la costa de Oaxaca' supported by PROMEP (2IR0707) to F. Benítez-Villalobos. The histological analyses were done at the Histology Laboratory of the UMAR. The authors are most grateful to A. López-Pérez, E. Robles, Ma. A. Esparza, A. López, F. Becerril and I. López for their assistance in field and laboratory work. This manuscript has been improved considerably by comments from 4 anonymous referees.

\section{LITERATURE CITED}

Avila-Poveda OH (2004) Ciclo reproductivo del caracol Pala Strombus gigas Linnaeus 1758 (Gastropoda: Caenogastropoda: Strombidae) del Archipiélago de San Andrés, Providencia y Santa Catalina, Caribe insular colombiano. MSc thesis, Centro de Investigación y de Estudios Avanzados del Instituto Politécnico Nacional, Mérida

Avila-Poveda OH, Baqueiro-Cardenas ER (2009) Reproductive cycle of Strombus gigas Linnaeus 1758 (Caenogastropoda: Strombidae) from Archipelago of San Andres, Providencia and Santa Catalina, Colombia. Invertebr Reprod Dev 53:1-12

Avila-Poveda OH, Colín-Flores RF, Rosas C (2009) Gonad development during the early life of Octopus maya (Mollusca: Cephalopoda). Biol Bull 216:94-102

Baker JR (1938) The evolution of breeding seasonality. In: DeBeer GR (ed) Evolution. Clarendon Press, Oxford, p 161-178

Benítez-Villalobos F (2005) Reproduction and larval biology of North Atlantic asteroids related to the invasion of the deep sea. PhD thesis, University of Southampton

- Benítez-Villalobos F, Díaz-Martínez JP (2010) Reproductive patterns of the abyssal asteroid Styracaster elongatus from the N.E. Atlantic Ocean. Deep-Sea Res I 57: 157-161

Benítez-Villalobos F, Martínez-García M (2012) Reproductive biology of the starfish Pharia pyramidatus (Echinodermata: Asteroidea) from the Mexican tropical Pacific. J Mar Biol Assoc UK 92:1409-1418

Borges M, Yokoyama LQ, Amaral ACZ (2009) Gametogenic cycle of Ophioderma januarii, a common Ophiodermatidae (Echinodermata: Ophiuroidea) in southeastern Brazil. Zoologia 26:118-126

Böttger SA, Walker CW, Unuma T (2004) Care and maintenance of adult echinoderms. Methods Cell Biol 74:17-38 Bower JR, Murphy JM, Sato Y (2002) Latitudinal gradients in body size and maturation of Berryteuthis anonychus (Cephalopoda: Gonatidae) in the Northeast Pacific. Veliger 45:309-315

Byrne M, Cisternas P, O'Hara T (2008) Brooding of pelagictype larvae in Ophiopeza spinosa: reproduction and development in a tropical ophiodermatid brittlestar. Invertebr Biol 127:98-107

Cuénot L (1888) Études anatomiques et morphologiques sur les ophiures. Arch Zool Exp Gén 6:33-82

> Falkner I, Byrne M (2003) Reproduction of Ophiactis resiliens (Echinodermata: Ophiuroidea) in New South Wales with observations on recruitment. Mar Biol 143:459-466

- Fenaux L (1970) Maturation of the gonads and seasonal cycle of the planktonic larvae of the ophiuroid Amphiura chiajei Forbes. Biol Bull 138:262-271

Giese AC, Pearse JS (1974) Reproduction: general principles. In: Giese AC, Pearse JS (eds) Reproduction of marine invertebrates, Vol 1. Academic Press, New York, NY, p 1-49

Grange LJ (2005) Reproductive success in Antarctic marine invertebrates. PhD thesis, University of Southampton

- Grange LJ, Tyler PA, Peck LS, Cornelius N (2004) Long-term interannual cycles of the gametogenic ecology of the Antarctic brittle star Ophionotus victoriae. Mar Ecol Prog Ser 278:141-155

Guest JR, Baird AH, Goh BPL, Chou LM (2005) Seasonal reproduction in equatorial reef corals. Invertebr Reprod Dev 48:207-218

Hendler G (1975) Adaptational significance of the patterns of ophiuroid development. Am Zool 15:691-715

Hendler G (1979) Reproductive periodicity of ophiuroids (Echinodermata: Ophiuroidea) on the Atlantic and Pacific coasts of Panama. In: Stancyk SE (ed) Reproductive ecology of marine invertebrates. University of South Carolina Press, Columbia, SC, p 145-156

Hendler G (1991) Echinodermata: Ophiuroidea. In: Giese AC, Pearse JS, Pearse V (eds) Reproduction of marine invertebrates, Vol VI. Boxwood Press, Pacific Grove, CA, p 356-510

Howard DW, Smith CS (1983) Histological techniques for marine bivalve mollusks. NOAA Tech Memo NMFSF/ NEC-25. NOAA, Woods Hole, MA

Lincoln RJ, Sheals JG (1979) Invertebrate animals: collection and preservation. British Museum and Cambridge University Press, London

Luna LG (1968) Manual of histologic staining methods of the armed forces institute of pathology, 3rd edn. McGrawHill, New York, NY

McEdward LR, Miner BG (2003) Fecundity-time models of reproductive strategies in marine benthic invertebrates: fitness differences under fluctuating model environmental conditions. Mar Ecol Prog Ser 256:111-121

> Mercier A, Hamel JF (eds) (2009) Endogenous and exogenous control of gametogenesis and spawning in echinoderms. Adv Mar Biol 55:1-302

Nagy IZ, Pieri C (1975) A new method for very precise volumetry of organs of irregular shape. Mikroskopie 31:70-72

Pearse JS (1968) Patterns of reproductive periodicities in four species of Indo-Pacific echinoderms. Proc Indiana Acad Sci 67B:247-279

Ramirez-Llodra E (2001) Reproductive patterns of deep-sea invertebrates related to energy availability. PhD thesis, University of Southampton

Ramirez-Llodra E (2002) Fecundity and life-history strategies in marine invertebrates. Adv Mar Biol 43:87-170 
Ramirez-Llodra E, Tyler PA, Billett DSM (2002) Reproductive biology of porcellanasterid asteroids from three abyssal sites in the northeast Atlantic with contrasting food input. Mar Biol 140:773-788

Roy K, Jablonski D, Valentine JW, Rosenberg G (1998) Marine latitudinal diversity gradients: tests of causal hypotheses. Proc Natl Acad Sci USA 95:3699-3702

Scherle W (1970) A simple method for volumetry of organs in quantitative stereology. Mikroskopie 26:57-60

Selvakumaraswamy P, Byrne M (1995) Reproductive cycle of two populations of Ophionereis schayeri (Ophiuroidea) in New South Wales. Mar Biol 124:85-97

Selvakumaraswamy P, Byrne M (2000) Reproduction, spawning, and development of 5 ophiuroids from New Zealand. Invertebr Biol 119:394-402

Sokal RR, Rohlf FJ (1995) Biometry: the principles and practice of statistics in biological research, 3rd edn. WH Freeman, New York, NY

Soong K, Chang D, Chao SM (2005) Presence of spawninducing pheromones in two brittle stars (Echinodermata: Ophiuroidea). Mar Ecol Prog Ser 292:195-201

Editorial responsibility: Christine Paetzold, Oldendorf/Luhe, Germany
Stancyk SE (1979) Reproductive ecology of marine invertebrates. Belle W Baruch Library in Marine Science, Vol 9. University of South Carolina Press, Columbia, SC

Stephenson A (1934) The breeding of reef animals. Part II. Invertebrates other than corals. Sci Rep Great Barrier Reef Exped (1928-1929) 3:247-272

> Stewart BG, Mladenov PV (1995) Reproductive periodicity in the euryalinid snake star Astrobrachion constrictum in a New Zealand fiord. Mar Biol 123:543-553

Tominaga H, Nakamura S, Komatsu M (2004) Reproduction and development of the conspicuously dimorphic brittle star Ophiodaphne formata (Ophiuroidea). Biol Bull 206: 25-34

Walton WH (1948) Feret's statistical diameter as a measure of particle size. Nature 162:329-330

Williams ME, Bentley MG (2002) Fertilization success in marine invertebrates: the influence of gamete age. Biol Bull 202:34-42

Wong NA, McClary D, Sewell MA (2011) The reproductive ecology of the invasive ascidian, Styela clava, in Auckland Harbour, New Zealand. Mar Biol 158:2775-2785

Submitted: April 25, 2012; Accepted: August 1, 2012

Proofs received from author(s): October 17, 2012 